\title{
STANDARDS AND COMPETENCIES OF THE EU - THE MARKET STRATEGIES OF FINANCIAL SERVICES IN THE BALKAN REGION
}

\author{
Nada Vignjević-Đorđević* \\ State University of Novi Pazar, Novi Pazar, Serbia \\ Šemsudin Plojović \\ International University of Sarajevo, Sarajevo, Bosnia and Hercegovina
}

New members joining the European Union, happily coincided with the economic rise worldwide. The investment industry has positioned itself at the time of European expansion in the emerging markets. Extended European capital market, preceded by a long period of preparation of the new members, in which they felt the positive effects of connecting with more mature markets. Experts point out that the World Bank policymakers eight new members of the European Union should adopt a proactive stance in taking further financial reforms and that in addition to the rapid growth of the banking system and stimulate growth in the form of non-banking financial operations. Increasingly important shareholders associated with the strengthening power of institutional investors. So stockholding strengthened with the help of representatives of institutions in the field of insurance, pension funds and investment funds. The subject of research are the impacts of changes in the insurance market taking into account the connection with the banking sector through a unique offer. The goal is to show greater dependence of the banking sector and insurance in the ever-growing competition with an innovative range of products. All the major part of savings managed by institutional investors. Savings realized the benefits of financial innovation, which have significantly lowered the cost of the invested money management services and improve the quality and diversity of investments. This "gathering" individual savings, have improved the efficiency frontier relations income-risk and on the other hand, over-sized achieve the economies of scale transactions. Also, depositors can expect a higher level of revenues for the same level of risk.

Key words: Market strategies, Financial services, Standards, Competencies, EU

\section{INTRODUCTION}

The general objective of the regional approach, which is defined by the European Commission [17, p.123-141], in addition to the consolidation of peace and stability in Southeast Europe and to encourage and assist its economic regeneration. Basic elements of this process, the European Commission has defined as:

- Development Agreement as the basis of new types of contractual EU's relations with individual countries of the Balkans;

- Developing and improving existing economic and trade relations;

- Developing existing financial assistance, particularly through new financial instruments (CARDS);

- The development of political and business dialogue, including regional level.
The strategy of economic reform and regional cooperation, which represents, in fact, asymmetric trade liberalization, and on that basis contributes to the changing position of the insurance company only one side has improved conditions for preferential imports from the Western Balkan countries by granting "emergency trade measures." Rules has expanded the scope of application of additional preferential measures, are duty-free treatment on $95 \%$ of goods originated from countries that are involved in the association.

The most important institutional sectors in the formation and use of the reservoir at the level of macro system, hence the component parts of commercial sources and placements are: 1. Economy 2. Education, 3. Population, 4. Bodies and Institutions, 5. Banks and other financial organizations and 6. Foreign Countries. Seen from 
a development point of view the most important economic sector positions in the formation of market and insurance resources and the use of credit. Complementary importance of a sector of the population.

These as well as changes in the environment and within the companies themselves potencial all the complexity of managing changes in marketing management. As managers of insurance will increase more systemic, rather than strictly commercial and insurance oriented. This means that managers will be more in insurance strategists than previous operators, in order to achieve the evolutionary position of insurance companies in the market conditions. It will be in the full sense of the present innovative, almost revolutionary trends characteristic of the overall business environment.

In the future we can expect a more rapid consolidation within the banking system $[8,52-68]$ and insurance, and increased competition, and from it will emerge more favorable conditions and a greater range of products that banks will offer.

Reconfiguration, download, connection pooling and insurance companies through capital competition faced with various forms of non-capital development and growth of enterprises. The globalization of business activity [15, p.49-61] favors the establishment of various "joint venture" investments and strategic alliances in order to take advantage of opportunities in the regional market.

\section{NATIONAL LEGISLATIVE HARMONIZATION WITH EU REQUIREMENTS}

Harmonization of legislation of Member States [1, p.31-38] relating to the integration of the domestic economy in the EU common market $[5,6,10]$, can be made positive and negative approach that is also described as "positive" and "negative" harmonization. Realization of positive integration consists in making of EU rules [9, p.1721] in a uniform manner applicable in all Member States. At the level of the common state, these properties have regulations / ordinances. As the regulations recognized the immediate application of the direct effect, and their uniform application achieves not only alignment, but also full alignment. Hence, in the theoretical sense rules are not a means of harmonizing the rights of member states, but a means to equalize the application is not transformed into harmonized national legislation, but remain as a single supranational regulations. Economic developments after the creation of the EU is characterized by two processes that occur simultaneously:

- - Harmonization of the national legislation of EU member states, and

- - Creation of specific subjects of business.

Responsibility of agencies and organizations in the public sector is much rigorous than the responsibility that is required in the private sector. For this, there are a number of reasons, most of which are based on the fact that proper and timely payment of taxes and other public revenues in the public interest, not the interests of individuals. On the other hand, services that service the ministries and other state organs intended for the population as a whole, not individuals. The users of these services can not go somewhere else and buy such a same service, if it considers that it is not getting the right value for your money, so it is necessary to establish mechanisms of accountability of public service providers which will ensure the proper regulation of the use of public funds.

Capital construction programs and plans investments are very important in every country, especially in countries in transition [21, p.97-112]. Nature and scope of investment for individual development projects assumed security in general require funding from real sources, such as budgets, loans from the country and abroad, grants and other funding sources. Determined and approved investment programs [22, p.264280] are implemented by signing a series of contracts between the state or state agencies or other organizations designated by the State, with a corresponding credit institutions and banks in the country and abroad, and from the state, public funds or organizations that are designated by the state (for example, the Development Fund, and the like) and the providers of the programs, service providers and other suppliers of material goods. Then, there are agreements between the State and the representatives appointed government bodies and regulatory authorities, on behalf of investors who oversee and control the execution of contracted projects and a number of other contracts for various brokerage and other services. As a rule, the development plans and programs are long and divided into shorter intervals, to facilitate their effective monitoring, registration, analysis and verification. In the im- 
plementation of "state" or investment contracts, or contracts which are related to the realization of investment plans occur in practice setbacks due to inefficiency, then exceeding the approved funds, financial loss, fraud, theft or damage to inadequately secured equipment, works and various other financial fraud, corruption and the like, see at Figure 1.

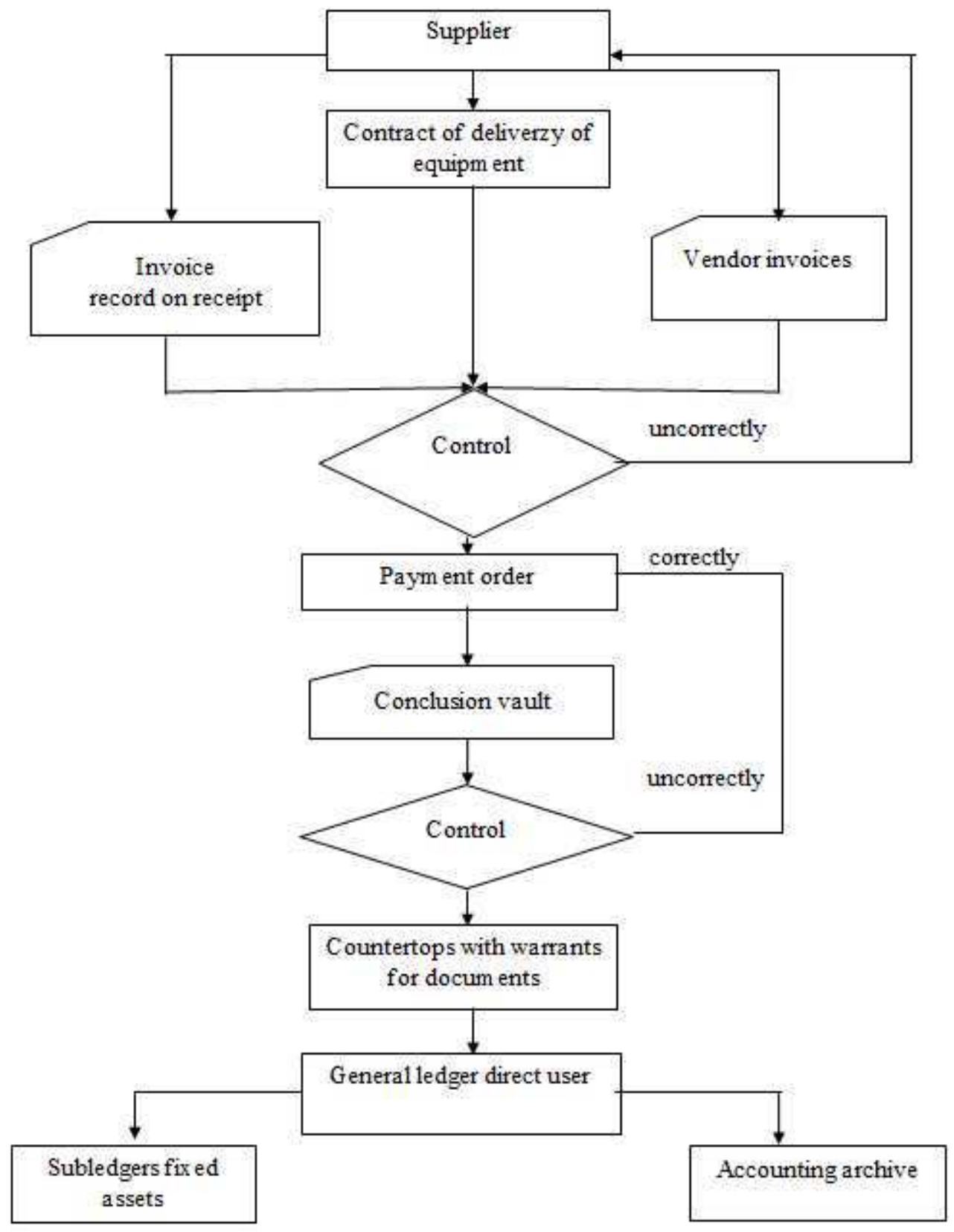

Figure 1: Marketing management in financial institutions Example procurement equipment

\section{MARKET SEGMENTATION AND CUSTOMER ANALYSIS OF INSTITUTIONAL SECTOR}

Market segmentation [14, p.136] is the process of identifying significant differences in the characteristics of the customers in order to divide the market into two or more groups of consumers for the purpose of: 1) The election of those parts of the market that the company that handles and 2) the creation of products and programs to meet the different needs of each customer group. The benefits of market segmentation [19, p.113-145] strategy are multiple: 1) To better identify marketing opportunities; 2) makes it easy to customize the marketing mix to target specific groups of consumers; 3 ) helps to better allocate marketing resources; 4) directs the positioning of the product to the consumers, and to competition; 5) directs the planning product development.

Market segmentation is desagregate and indicates that there are different demand curve 
where until recently it was assumed that there is only one. In a strategy to differentiate the company is trying to control the market and isolate their products from price competition from other companies, using very intensive promotion as a marketing instrument. Segmentation strategy based on the heterogeneity of the market and the fact that there are a number of smaller homogeneous markets due to different consumer preferences.Segmentation as a strategy of adopting products to the needs and demands of customers. Strategy of segmenation is winning market depth.

In order to create a market segmentation strategy to ensure it is necessary to do more activities and bring a greater number of decisions. Activities begin with the identification of the dimensions of market segmentation, to create the relative profiles of market segments on the basis of these activities provide for total market potential for each segment. Within each segment to identify the factors of competition, and then define the marketing mix for serving each segment, offering its full range of insurance products were often going in banking business.

Marketing environment consists of external factors [3, p. 31-37], which directly or indirectly affect the purchase of the inputs and generate outputs. Marketing environment can be understood as a set composed of six categories of power: political, legal, regulatory, social, economic and technological. Regardless of whether you are changing fast or slow, power environments are always dynamic. For insurance companies changes in the environment creates uncertainty, threats or opportunities. Easy future is not entirely predictable, companies can evaluate what is going to happen. It is safe to say that the same will continue modifying their marketing strategies in response to a dynamic environment. Marketing directors in the insurance companies [20, p.264-285] must be ready not to miss changes in the forces of the environment and to take advantage of opportunities and be prepared when the disadvantages environment, otherwise the company can be found in big trouble. Environmental analysis is the process of evaluation and interpretation of information obtained from market research. The management of the company evaluates.information.concerning.the.accuracy,. trying.to.solve.the.inconsistencies.in.data.

Establishe significance of certain findings: Re- configuration, download, connection pooling and insurance companies through capital competition faced with various forms of non-capital growth and enterprise development. The globalization of business activity favors the establishment of various "joint venture" investments and strategic alliances in order to take advantage of opportunities in the regional market.

Resistance of top management changes [7, p.13-18] may represent one of the major obstacles to the successful implementation of a transformational process. There are a number of reasons, especially in our country, which is why top management does not undertake changes. Some of the most important are: fear of change, whereby the process of managing changes immanent resistance, which is a result of fear of the unknown and experiencing changes as a threat and a possible source of uncertainty;

- Management is not aware of the business situation of the insurance companies, because the maintenance and improvement of competitive advantage depends primarily on the ability of timely detecting and understanding changes in the external environment,

- Wrong to interpret or ignore the available information, as insufficient transparency changes may have resulted in basis in the assessment of the current situation;

There are no clear vision and strategy for the transformation process, because leadership is a critical factor for the success of management changes which practically means that the leader who recognizes the need for the change and questions the basic assumptions about business and the functioning of the company;

Interest in maintaining the current situation because it means a loss of privileges or conditions in our retention of the existing situation allows you to get over the private sector and through various forms of non-institutional privatization achieve significant revenues;

The management of insurance companies [2, p.21-25] should not be too much time devoted to operational issues, keeping in mind, everyday ways to review the functioning of the company, that management by listed companies most part of the time is spent removing crisis, emergency situation, which means that management actions aimed at eliminating the evident crisis situation and less the timely warning of opportunities and threats: The success of the past can be a cause 
of blindness in the current situation, because of the modern insurance company requires not only adequate sensitivity and speed of reaction to changes already and start the changes through innovation;

Not understanding the insurance company's mission, its competence and the basic ways to achieve competitive advantage, because each company a kind collection of unique resources and the capabilities that provide the basis for a competitive advantage and strategy.

Companies must decide precisely how and where to channel your product or insurance products in selected market segments. The needs and desires of the insured in the target markets must be materialized in the form of a marketing mix. It is particularly important to the insured experienced service insurance and how it is positioned relative to competitive offerings. Through analysis, marketing director of the company seeks to describe the current changes in the environment and those anticipated in the future. By evaluating the change manager should be able to identify possible threats and opportunities related to fluctuations in the environment [18, p.74].

Understanding of the current situation and taking into account the threats and opportunities arising from changes in the environment, helps marketing directors in ensuring that assessment actions undertaken and the results of marketing efforts to present and develop marketing strategies for the future.

In dealing with the forces in the marketing environment, can be applied to two general approaches: accept power environments like those that can not be controlled, or to confront them and try to shape them. If the power of the environment are viewed as the same, which is impossible to control, the company remains passive and reactive to the environment. Instead of trying to influence the strength environments, its directors seek marketing and factors affecting the expected service as propaganda, oral propaganda and previous experience.

External marketing has a direct impact on the promotion of insurance services and indirectly - by tailoring service offers insurance in accordance with the requirements and desires of the insured and the creation of marketing mix on previous experience and oral propaganda. Given that the indirect impact of the consequences of previous results, it is based on realistic possibilities and capabilities of the company, which affects the formation of previous expectations and in most cases is completely objective.

Promoting the services offered by the company directly affects the formation of previous expectations. What is the level of the previous expectations of higher quality to be higher, to get it insured and those perceived. Increase expected implies the necessity to improve performance objectively measured by quality, to the perceived quality was higher. Otherwise, the insured tend perception of low quality, even in conditions where it is objectively measured quality satisfactory. The reason lies in the fact that they are not fulfilled (unreasonably) high expectations (actually at the same time is less and the initial inclination of the potential of the insured to conclude insurance, but higher his revolt when they realize that the quality of services delivered is not at the level of promises).

Wrong is the determination of those insurance companies that are prone to stress the major communicating the benefits and superiority over the competition, as the expectation of greater created, the greater the danger of a final impression of poor quality.

Forming a community risk is a basic assumption of the existence of insurance. Members of the community risk (companies, banks, cooperatives, private individuals) each associate in order distribution of risks, and for common security against unpredictable events, lie of the same risks that threaten them. By forming a community risk is observed that the basic motive of purchase of insurance by the insured person providing the possibility of occurrence of adverse events and other equally important motives such as: security, confidence and protection.

The behavior of the insured affects a whole range of factors which may be psychological in nature. Environmental factors of a psychological nature: cognitive behavior, and affective behavior.

Cognitive behavior implies the process of receiving information to reaction specific problem. The starting point of knowledge, thinking and beliefs, which are formed under the influence of experience and are stored in the memory of consumers.

Environmental factors that can have various forms of influence on the behavior of the insured, the culture, the family, reference groups, social classes and strata, status, lifestyle, etc. These 
factors may affect both cognitive and affective system of the insured, and its behavior. Culture has a basic and broadest impact on people's behavior as consumers. Culture defines models of behavior, rules, customs and norms which its members adhere. In those countries where there is a tradition of culture of insurance, there is also the most developed insurance market and vice versa, unfortunately in our country, the culture of the insured is at a low level of objective and subjective reasons.

Reference groups are groups whose behavior is a person's reputation. The family is the primary reference group. It affects a number of ways to the formation of values, beliefs and behaviors of individuals and by economic status, emotional support, socialization of children and lifestyle. These are some of the most influential sociological factors that influence the behavior of the insured. From the macroeconomic factors most influential on the behavior of the insured are: national income, social organization, and regulation. The higher national income and higher standard of living and thus a greater need for insurance.

\section{STRATEGIC MARKETING MANAGEMENT OF FINANCIAL INSTITUTIONS}

The first phase of value creation and flow delivery option values as a task of strategic marketing of financial institutions. Segmentation, targeting and positioning are the essence of strategic marketing. Creating and communicating values are a matter of tactical marketing. The space between the marketing strategy and the insured person to whom it is directed, and is filled with tactical activities.

The aim of marketing strategy [14, p. 36] may be to increase profitability (increased sales of insurance policies already existing policyholders - increasing customer loyalty) and increasing market share in existing markets or new or both markets (attracting new contributors). Also, target marketing strategies institutions can be both of these merged into one which is generally the practice. Before formulating the objectives of the marketing strategy, according to which it would be directed segmentation, targeting and positioning, it is necessary situational analysis of financial institutions.

Situation analysis provides relevant information on the sale of insurance policies, the cost of the insurance companies, competitive insurance companies and a variety of factors in the macroenvironment. Then, market data, as defined. Strong market position means that companies have a large market share and are usually profitable. It is thought that the market share is usually not required to generate profitability. Profitability is a result of business strategies, such as providing high quality insurance services, etc. providing superior insurance services from competitors leads to greater loyalty of the insured, whereby the company will have fewer costs about attracting new customers, which will lead to profitable operations. Profit impact on marketing strategy (PIMs), is not only used to diagnose problem areas or recognition of opportunity, but also to assist in the allocation of resources among business units. PIMs can marketing directors of insurance companies that serve as the formula of success or prescribed guide for guaranteed successful strategic action plans. These models are a supplement, not a substitute for your own judgment marketing director.

Characteristics non-financial companies in the business of insurance relating to the internal organization of the work itself which includes the internal marketing. Basic characteristics of the non-financial business relating to the functioning and internal benchmarking, whose focus is to compare the specific activity of the product, service, logistics and other top organizations independent of the type of activity. Internal benchmarking is very interesting for companies that have jagged organizational structure. Given the fact that the insurance company characteristic structure in the form of territorial dislocated organizational units in the form of branches, where the business makes a similar set of operations that can be a very simple way to compare, recommended intensive use of benchmarking for insurance companies. For example, the insurance company that has branches in various regions can be compared to work in them, in order to find the best practical solution, which provides a distinctive quality to the customer's insurance products or identify potential savings. Branch insurance companies we considered strategic business units defining the research of the insurance market:

The database includes diagnostic and prescribed information to help in the analysis of marketing activity and formulating marketing strategies. The analysis focuses on the opportunities, issues, 
resources and opportunities [4,13]. Contents of market research that should help the insurance company when choosing strategies, identified more than thirty facts that affect the company's operations, and the same would comprise the following:

- -Shares in relation to the largest competitor

- -The quality of the product compared to the competition

- -Rates in comparison with the competition

- -Marketing efforts against the competition

- Models of market segmentation

- -The rate of introduction of new products

- -The structure of the production process

- -Capital intensity

- - The degree of vertical integration

- -Capacity utilization.

The productivity of capital equipment, the productivity of employees, budgets research and development, advertising and promotion budgets. These facts can be divided into three sets of variables: (1) those related to the structure of the markets in which the company competes; (2) that describe the company's competitive position within that market; (3) relating to the strategy chosen by the company.

The criteria based on which form segments related to the fundamentals of segmentation consists of several groups, the most important are the following:

The first group consists of the most commonly used criteria subgroups, which are related to the geographic location makes the buildings and customers on their demographic characteristics related to: age, gender, income, family life cycle, etc. It is the segmentation criteria, which are the simplest and for which data are generally available in all statistical sources secondary data. However, what makes them easily accessible, while placing them in a group of necessary but not sufficient conditions for the realization of the segmentation and the formation of segments. Some authors call them skeleton - skeleton segmentation which must be supplemented by other criteria, primarily those from the group of consumer behavior.

Different customer preferences open problem of defining the service offers a variety of market segments, therefore, it is appropriate on the basis of information on the benefits that customers want and expect from a market segment based on criteria from the group of consumer behavior:

- Uses required by the service,

- Expectations,

- Tendency towards building long-term relationships,

- Willingness to engage in the process of providing services - responding to marketing factors (factors of supply) - the volume of transactions.

EXAMPLE: To define market segments is carried out market research related to qualitative research, focus group discussions, groups of 610 participants, duration of $90-120$ minutes. This technique allows a deeper understanding of the behaviors, attitudes, motives, etc. the insured, as well as the collection of large quantities of information in a relatively short period of time. Results of focus group discussions can not be generalized to the population, because the sample is too small. Taking into account that the subjects chosen to advance to the selected criteria, opinions should be considered typical only for this specific segment of the population: the aim of the research: examining the attitudes of participants towards insurance companies. Specification of objectives:

1) Knowledge and attitudes towards different types of insurance,

2) The use of and satisfaction with services insurance house,

3) 3) Trust in the various insurance companies: private / public, domestic / foreign,

4) The perception of the ideal home insurance,

5) The method of information about insurance companies,

6) Perception of individual insurance companies.

The insurance company can choose between three alternative strategies align its resources with potential markets: 1) Mass market strategy; 2) The strategy of concentration on one market segment, and 3) multiple market segmentation strategy. Strategy or the so-called mass market undifferentiated marketing response when the market is homogeneous in its demands. With one combination of marketing mix, based on a single product, the company strives to meet the needs of all customers. This strategy is very diffi- 
cult to perform in the insurance market, primarily because it is not homogeneous in its demands. The strategy of concentration on one market segment concentrated marketing strategy is appropriate when there is a well defined group (segment). The company produces one marketing mix for the special needs of one segment of the target from several market segments; it is one brand of products or services tailored to a group of consumers. Competitive advantage is gained specialization or uniform - a good marketing mix adjustment needs of the target market segment. This segmentation strategy is very present in the insurance market (pension insurance, voluntary health insurance, life insurance, etc.).

The strategy assumes multiple segmentation orientation in several market segments to form a marketing mix for each segment individually. The company uses the differences between market segments, trying to achieve maximum participation in the market. The company needs to have great sources. Create different frames for each price segment. This strategy of segmentation in the insurance market can only carry out a large insurance company. Branch insurance companies we considered are strategic business units. The model is applied and the analysis was made on the case following the Balkan countries: Bosnia and Hercegovina, Serbia, Montenegro and Macedonia. Market segmentation is an activity that precedes the selection of target markets, maximizing long-term workload, long-term increase in profit maximizing short-term workload, increase short-term profits, affects the organizational image, the reasons for the offensive strategy for defensive reasons stgrategy, internal resources / capabilities, relative readiness tender, etc.

The attractiveness of the segments are classified into several groups:

First growth rate - the average annual speed of growth of income sources used by that segment. It can be used and the overall average rate of growth. Of course, when determining the rate of growth of the segment, to be taken into account as much (or not) stimulating business environment.

Available second segment size - One way to calculate is to estimate the total income of this segment during the specified time, less inaccessible income, regardless of the invested funds. The second most common way is to use the size of the entire segment, it does not mean that the manager brings any court, which could distort the real picture. This method is recommended.

Third potential profits - it is much more difficult to calculate, due to significant fluctuations depending on the segment. For example, for the evaluation of potential profit segment can be used Porter's model of five factors, such as the Table 1.

Table 1: Porters model a factor of five

\begin{tabular}{|l||}
\hline Subfactors potentials Rang segment profit \\
\hline $\begin{array}{l}\text { subfactor points pondering subfactors (rank x pon- } \\
\text { dering value) }\end{array}$ \\
\hline 1 Competitive power and cleanliness 50 \\
\hline 2 Risk of supstitute 5 \\
\hline 3 Risk from sojourned 5 \\
\hline 4 Power of suppliers 10 \\
\hline 5 Power of buyers 30 \\
\hline Points a factor of profit potentials \\
\hline $\begin{array}{l}\text { Provenance: M. McDonal, L. Dunbal, Segmenta- } \\
\text { tion Marketplace (Market Segmentation), Clio, Bel- } \\
\text { grade, } 2003, \text { p. } 136\end{array}$ \\
\hline
\end{tabular}

Subfactors are supstitutes to profit potential is. Pondering value added up to 100 to get ponts a factor of profit potentials.

EXAMPLE:

In the insurance case, subfactors can be, as the Table 2.

Table 2: Porters model a factor of five different services

\begin{tabular}{|l||}
\hline Subfactros Rank segment Pondering \\
\hline large, medium, small $\mathrm{x}$ value points pondering \\
\hline Unmet needs for insurance service efficiency 35 \\
\hline Unmet needs for Favors insurance certainty 35 \\
\hline Potential is the price $\quad 10$ \\
\hline Competitive cleanliness \\
\hline Costs of entry to segment 10 \\
\hline Total: 100 \\
\hline
\end{tabular}

Origin: Research by authors

A factor of three groups (growth variable and obtain it) could be a hundred regards, market insurance to add, for example, political risk and political elements of the municipality. For in-law a factor of attractiveness of the segment pondering the relative greatness to one another, according to specific requirements of insurance company, as the Table 3. 
Table 3: Segmentation of insurance market and profit potential

\begin{tabular}{|l|}
\hline Growt rate 40 \\
\hline Accessible size segment $\quad 20$ \\
\hline Profit potential is 40 \\
\hline Total: 100 \\
\hline
\end{tabular}

Origin: Research by authors

In some coincidences, it can be, to get to pondering growth (That need to small other sentences). Elements of these, may form the combination with a specific market elements of.

\section{CONCLUSION}

In the current extremely difficult economic conditions, onset of the global economic and financial crisis, financial liquidity, declines in economic activity and in connection with this great fall collection of value added tax and other public revenues, severely affected regular functioning of the public sector. Current efforts towards improving marketing management strategies practices constitute an unavoidable aspect of the transition process, as they are directed towards cristaling legal and regulatory framework, building confidence among domestic and foreign investors and strengthen financial markets and banking system. The regime of movement of foreign capital is arranged a series of regulations. Of particular importance are: the Law on Foreign Investment, the Law on Securities Market and Other Financial Instruments Act, the credit relations with foreign countries, the Foreign Exchange Act, the Payment System Act, the Act on Investment Funds. After more than deceide transitional process, Serbia has largely succeeded in introducing the key legal and economic institutions of the market economy. Stability of a financial system depends on the ability of the system to respond to the demands of time in which to exercise its functions. If these functions are not in fully implemented in the laws and regulations governing the financial system of a country, it is understandable that there is a need for such legislation and such a system to be aligned with the current needs and requirements of the financial markets. All the major part of savings managed by institutional investors. Savings realized the benefits of financial innovation, which have significantly lowered the cost of the invested money management services and improve the quality and diversity of investments. This "gath- ering" individual savings, have improved the efficiency frontier relations income-risk and on the other hand, over-sized achieve the economies of scale transactions. Also, depositors can expect a higher level of revenues for the same level of risk. Preserving the integrity of the market it is imperative that the occurrence and behavior of all participants, institutions, capital markets, economy, various occupations and professions. Upgrading the regulatory framework in discovering and sanctioning of occurrence as well as training in this area should be part of regular professional development to state control bodies, self-regulatory bodies and brokers, and other professionals associated with the capital market. Also, technical development requires special attention of all participants in the market due to the fact that it opens up new possibilities of abuse, but also new tools for their timely sanction. Continuous education should be a mandatory part of the profession of financial market participants.

\section{REFERENCES}

1) A Critical Review, (2003). OECD Development Centre, Technical Papers No. 210, p. 31-38

2) Arens A, Elder R, Beasley M, (2003), Auditing and assurance sevices, Prentice Hall, Pearsons Education International, New Jersey, p. 21-25

3) Mark Beasley, Auditing and assurance services, Ninth Edition, Prentice Hall, Pearsons Education International, New Jersey, p. 3137

4) Bergbrant M C., Campbell K T., Hunter D M., Owers J E., (2016), Does Deposit Insurance Retard the Development of Non-bank Financial Markets? Journal of Banking \& Finance, Available online 8 February 2016, doi:10.1016/j.jbankfin.2016.01.013

5) Bofinger, Peter and Wollmershauser, (2011), Is there a third way to EMU for the accession countries?, www.uni-magdeburg.de, retrieved on August 30 th, 2014

6) Council Regulation, EC, No 2007/2000.

7) Davis G. And Useem M., (2003), Top Management company Directors and corporate Control, pettigrew and Wittington, .p. 13-18

8) Frey R, Kerl C (2015), Multinational banks in the crisis: Foreign affiliate lending as a mirror of funding pressure and competition on the 
internal capital market, Journal of Banking \& Finance, Volume 50, January 2015, Pages 52-68

9) Jeswald S. W. (2002), Corporate Governance in The UNECE Region, UN/ECE, Geneva, 36, p. 17-21

10) Frommel Michael, Volatility Regimes in Central and Eastern European Countries, (2006), www.wiwi..uni-hannover.de, retrieved on September 15 th, 2013

11) Keller, K. L. (2006), Marketing Management, Data status, Belgrade p. 36

12) Lanning MJ and Michaels EG, (2003), A Business is a Value Delivery System, Clio, Belgrade, p. 74

13) Magretta Joan Understanding Michael Porter: The Essential Guide to Competition and Strategy Hardcover - December 6, 2011 by Publisher: Harvard Business Review Press; 1 edition (December 6, 2011), 256 pages

14) McDonal L. Dunbal M., (2005), Market Segmentation, Belgrade, Clio, p. 136

15) M. Beer and N. Nohria, (2005), Cracking the Code of Change, Harvard Business Review, May-June, p. 49-61

16) OECD, Organization for Economic Cooperation and Development. [Online] Available: www. oecd.org., retrieved on October 3 th, 2015
17) Tondl G., (2003), Regional Policy in the boock: The Economics of the European Union Policy and Analysis, Third Edition, Edition by Mike Artis, Frederick Nixson, First Published, New York, p. 123-141

18) ICC, International Chamber of Commerce. [Online] Available: http://www.iccwbo.org/, retrieved on January 10 th, 2016

19) Vignjević-Djordjević N, (2005), Marfin marketing in finance, Belgrade, Europress, $\mathrm{p}$. 113-145

20) Vignjević-Djordjevic N, Zarković N, (2010), Insurance law, institutions, management, Belgrade, Finegraf, p. 264-285

21) Vignjević - Đorđević N. (2009). Corporate governance and regulation - the development of public property, competitiveness and transparency of the market. Association of Economists of Serbia, Kopaonik Business Forum, p. 97-112

22) Vignjević Đorđević N., (2014) Corporate governance: state and trends in the region - a regulatory approach, Ekonomika preduzeća, UDC 65, YEAR LXII, september-october 2014, pp 264-280 ISSN 0353-443X

Paper sent to revision: 24.01.2016.

Paper ready for publication: 15.03.2016. 
doi:10.5937/jaes14-10064

Broj rada: 14(2016)1, 369

\section{STANDARDI I NADLEŽNOSTI EU - TRŽIŠNE STRATEGIJE FINANSIJSKIH USLUGA U REGIONU BALKANA}

\section{Nada Vignjević Đorđević, Državni Univerzitet Novi Pazar, Novi Pazar}

Ulazak novih članica u Evropsku uniju, srećno se poklopio sa ekonomskim usponom širom sveta. Industrija Investicionih ulaganja se pozicionirala u to vreme ekspanzije rasta na evropskim tržištima i na tržištima zemalja u razvoju. Došlo je do širenja evropskog tržišta kapitala, kome je prethodio dug period pripreme novih članova, u kojima su se osetili pozitivni efekti povezivanja sa zrelijim tržištima. Stručnjaci Svetske banke ističu da se razvojne politike ove svetske organizacije, reflektuju na osam novih članova EU. Evropska unija bi trebalo da usvoji proaktivan stav u preduzimanju daljih finansijskih reformi i da pored brzog rasta bankarskog sektora stimuliše i rast u obliku nebankarskih finansijskih usluga. Rast i uloga velikih akcionara, takođe, koincidira i združena je sa jačanjem uloge institucionalnih investitora i u tom smislu, jačanti ulogu stejkholdera zajedno sa predstavnicima finansijskih institucija iz oblasti osiguranja, penzionih fondova i investicionih fondovava. Najvecim delom štednje upravljaju, upravo, institucionalni investitori. Uštede ostvaruju prednosti kod finansijskih inovacija, koje značajno smanjuju troškove investicionih ulaganja i poboljšavaju kvalitet i portfolio ulaganja. Ovaj "skup" pojedinačne štednje je poboljšao efikasnost risk menadžmenta $i$ sa druge strane, višestruko povećao postizanje ekonomije obima transakcija. Takođe, štediše mogu da očekuju viši nivo prihoda za isti nivo rizika.

Ključne reči: Tržišne strategije, Finansijske usluge, Standardi, Kompetencije, EU 